\title{
COMPARATIVE ANALYSIS \\ OF POSTPOSTMODERN METHODOLOGICAL CLAIMS
}

\author{
Karyna Babko \\ Postgraduate Student, National Aerospace University "Kharkiv Aviation Institute", Ukraine \\ e-mail: korywrc@gmail.com, orcid.org/0000-0002-6907-3924
}

\author{
Abraham Kome \\ Ph.D., John Paul II International University of Bafang, Cameroon \\ k_abra2006@yahoo.fr,orcid.org/0000-0001-7326-227X
}

\section{Summary}

Today, the relevance of the study of theories of postpostmodernism is due to several factors. Historically, we can observe the changes taking place in the development of society in connection with the origin and formation of different eras. Also, under these influences, the cultural, social, psychological, moral and technological spheres of life are transformed. We are now on the verge of a new era, and therefore an important aspect is the study of its key aspects.

The article considers the problem of modern society regarding the definition and derivation of the concept of culture at this stage of the development of civilization. The main idea of the article is the alleged end of postmodernism and the obvious emergence of some new modernism.

The article is devoted to a detailed review and analysis of the main postpostmodern foreign concepts of the modern cultural paradigm.

Data are presented on theories such as metamodernism, hypermodernism, alternativemodernism, digital modernism, automodernism and performatism.

After reviewing and analyzing many different cultural phenomena that arise in this period, we can conclude that it would be unambiguous to reject one theory and put another in its place. Each of the theories has pronounced distinctive characteristics based on real factors and emphasizing the characteristic changes in the emergence of a new era. Therefore, it is advisable to look at the concepts presented through the prism of complexity, then a qualitative and complete perception of the surrounding reality will develop.

Keywords: metamodernism, automodernism, hypermodernism, altermodernism, digimodernism, performatism.

DOI https://doi.org/10.23856/3903

\section{Introduction}

Today humanity is at a certain stage of cultural, social, moral, aesthetic, spiritual, scientific and technological development. It does not stop there but rapidly and progressively steps forward to evolving, cognizing, communicating, researching, experimenting and interacting with the surrounding space resulting in new conceptual fields, models and developments. We are involved in this process related to the change of historically developed cultural paradigms. From the point of the philosophical picture of the world view it is possible to notice changes that influence radically on the general conceptually comprehensible context of a person.

Recently, a large number of various discussions have been observed among specialists in socio-humanitarian knowledge on the basis of the explication of the concept of man including in the light of the alleged concept of a modern and postmodern character. In the course of discussions, 
it comes to the realization that neither the categories of modernity nor the categories of postmodern fully satisfy the requirements of current reality. Moreover, the values of modernism and postmodernism cross out their potential in connection with the new expanding boundaries of the knowledge of the world. At the turn of the twentieth and twenty-first centuries an aggregate of views and concepts called "post-postmodernism" began to crystallize in the intellectual environment.

With a fairly short period of existence, the new worldview has given itself many names, which does not always clarify its ideological claims. Today, the following names are in use: post-postmodernism, digital modernism, pseudo-modernism, metamodernism. The concept of postpostmodernism can be considered generic in the above series, at least phonetically presupposing some kind of sequence, for the prefix post-supposedly can explain at least something (Kuzneczov, 2019). A very tautological term "postpostmodernism" is proposed as a conditional temporary and rather vague concept.

It seems to us that it is necessary to explicate the "key" concepts of post-postmodernism. In our opinion, it is required to clarify the logical concepts that postulate the phenomenon of "postpostmodernism".

A new concept claims to replace postmodernity, although it is far from unique in its scope and in the vastness of the information space one can find its following definitions:

"Postpostmodernism - a term for updating the understanding of the tasks of critical theory, philosophy, art, literature, architecture and culture by overcoming postmodernism" (Postpostmodernism,2020).

"Digimodernism is a new cultural paradigm based on the impact of computerization and interaction with new advanced technologies".

"Altermodernism is a concept of cultural development which implies many equal opportunities, alternatives in the overall process of cultural development".

"Auto-modernism is a direction of Western cultural philosophy, which includes a correlation of mechanical automation and an increased level of personal autonomy, in connection with the emergence of technical means".

"Metamodernism is the concept of a young Dutch philosophers who claims to be the title of a new cultural paradigm. A key aspect in this concept is the concept of oscillations between postmodern and modern".

"Hypermodernism is a phenomenon based on two factors - increased capitalism and competition, on the one hand and on the other hand it is an explosion of technology and communications contributing to cultural "instantness" and "speed".

"Performatism is a concept that considers modern culture as the integrity of an object and semantic integration with an object, thereby finding its manifestation in the multiplicity of chronotopes".

One of the features of post-postmodernism is that this trend not only refuses intertextuality but moves to a qualitatively new level of perceptual recreation and cultural layers of information, in which virtual reality occupies one of the key positions. Idea of "hyperreality" is one of the basic ones.

However, in postmodern times the concept of "hypereality" was already mentioned. The study and development of this problem involved Jean Baudrillard. Actually this term takes its roots from the philosophy of postmodernism and it is a phenomenon of simulation of reality. According to J. Baudrillard the main component of hypereality is a certain structural unit called "simulacrum." Accordingly, we can judge that the phenomena of "hypereality" and "simulacrum" continue to exist today due to the wide expansion of the Internet, informational and communication technologies. Are these concepts complete reflection of the reality of the new 
era? There are some doubts. Perhaps this is exactly what was borrowed from the postmodern and this may be one of the components of a large and complex "new modern".

The purpose of this article is to familiarize yourself with the various methodological claims that have emerged in the light of the emergence of a new era as well as a detailed description, detailed analysis and comparison of the presented concepts.

The field of research of the so-called postpostmodern cultural and historical period is very diverse and has received coverage in a number of scientific areas.

\section{Digimodernism}

Let us pay attention to the English philosopher Alan Kirby, who, while developing and researching this problem, introduced the term "Digimodernism". At the beginning, the author called his concept pseudo-modernism and later renamed it digimodernism.

First of all, the pseudo-modern cultural phenomenon par excellence is the internet. Its central act is that of the individual clicking on his/her mouse to move through pages in a way which cannot be duplicated, inventing a pathway through cultural products which has never existed before and never will again. This is a far more intense engagement with the cultural process than anything literature can offer, and gives the undeniable sense (or illusion) of the individual controlling, managing, running, making up his/her involvement with the cultural product. Internet pages are not 'authored' in the sense that anyone knows who wrote them, or cares. The majority either require the individual to make them work, like Streetmap or Route Planner, or permit him/her to add to them, like Wikipedia, or through feedback on, for instance, media websites. In all cases, it is intrinsic to the internet that you can easily make up pages yourself (eg blogs) (Kirby, 2006).

According to the author digimodernism positioned itself as a new cultural paradigm based on the influence of computerization and the latest technology. It should be emphasized that speaking of digital technologies we have in mind some technical means with which we achieve our goals and objectives. We believe that these tools are designed to facilitate and improve our lives. However, with over time it should be noted that not only digital technologies are our tool, but we are transformed under their influence and we are the product of the influence of the era of digimodernism. It was these changes that the British professor at Oxford University and cultural critic A. Kirby laid the foundation for his concept. According to A. Kirby, digimodernism decisively shifts postmodernism and manifests itself as a new cultural paradigm of the 21 st century. It should be emphasized that in its purest form the phenomenon of digimodernism represents a revolution in the nature of text as such which is clearly reflected in the Web 2.0 platform's Internet applications (blogs, chat rooms, forums, message boards, Wikipedia, Facebook, Twitter, etc.) Such textuality is progressive, random, short-lived, and has blurred boundaries: it exists in its own current development; its content is completely open to consumption although it is controlled secretly; it does not become obsolete and does not recover in its original form; its temporal and spatial boundaries although noticeable and it can be still established with great difficulty. Thanks to We b 2.0 applications, diaries, encyclopedias, letters and maps have already given way to email, text messages, Google or Yandex cards, etc.

In addition, digimodernism directly affects television. This is manifested in the emergence of more and more reality shows, blogs. Digitization also influenced the film industry by spreading a computer graphics interface that transformed the foundation of cinematography. All of the above allows us to define digimodernism as a new type of textuality; impact of computerization; new authorship, production and consumption; a new kind of story and a new way of expressing oneself. 


\section{Automodernism}

It is important to note that in order to comprehend the subsequent concept, we need to keep in mind a number of technologies that are used in the modern world: cars, personal computers, word processors, smartphones, smart watches, portable iPods, blogs, television with remote control, computer FPS games, robotics and more.

Robert Samuels laid the foundation for his research on the concept of "Auto-Modernism." According to the author, auto-modernism is a symbiosis of a high level of mechanical automation and the enhanced sense of personal autonomy. Such an unexpected and innovative combination of autonomy and automation can be perceived as a defining confrontation of modern life. It is important that while automation traditionally leads to the loss of personal management and control the level of autonomy is characterized by an increase in individual freedom. However, auto-modernism constantly combines these two antithetic forces in an unexpected way.

Unfortunately, in the perspective of auto-modernism the question of whether new technologies provide false or real autonomy and democracy is becoming increasingly vague since being involved in the environment of a new era, people don't able no longer to distinguish between real and quasi-real identities. Although the author of this theory tried using the empirical method to analyze the nature of the new era, at the same time, the direction of his research is reflected in a narrower plan such as "autonomy and automation" which covers a small spectrum of the life of society as a whole.

\section{Altermodenism}

No less important is the opinion of the French curator, cultural critic and art critic Nicolas Burrio, who put the concept of "Altermodernism" in the basis of his theory implies many equal opportunities, alternatives in the overall development process.

Altermodernism arises due to the interaction of agents from different cultural and geographical locations. To understand each other they translate the signs of their culture into the language of the signs of another culture, transcode information from one format to another, i.e., the process of creolization occurs. Burrio Manifesto "Altermodern. Postmodernism has died" defines it this way:

"A new modernity is emerging formed by the era of globalization in its economic, political and cultural aspects - the culture of almodernity. More intensive communication, travel and migration determine our lifestyle. Our daily life consists of moving through the landscape of a chaotic and crowded world. Multiculturalism and identity are embraced by creolization: artists are now embarking on a creative path in a globalized culture. The new versatility is based on translations, subtitles and dubbing. Today's art explores the connections that text and image, time and space form between itselves. The primary responsibility for a new globalized perception rests with artists. They cross cultural landscapes overflowing with signs and pave new paths between the numerous formats of expression and communication” (Komarniczkaya, 2009).

\section{Metamodernism}

Attracting attention in terms of the studies problems of the work of Dutch scientists and philosophers Timotheus Vermeulen and Robin van den Akker. In 2010, they presented in their essay "Notes of Metamodernism" the concept of Metamodernism which provoked considerable controversial discussions among philosophers, sociologists and cultural scientists. The authors note that the concept of "oscillation" is the fundamental and key form in this concept. In the 
process of developing the theory, the authors came to the conclusion that metamodern is determined by oscillation, i.e. oscillation between a typically modernist commitment and a distinctively postmodern alienation.

It should be noted that from the point of ontological view, metamodernism sways along the trajectory of the pendulum between the modern and postmodern eras. It oscillates between the enthusiasm of modernism and postmodern ridicule, between hope and melancholy, between simple-mindedness and awareness, empathy and apathy, unity and multiplicity, wholeness and splitting, clarity and ambiguity. Definitely swaying back and forth, back and forth, metamodern is trying to overcome the paradox of the interaction of modernism and postmodernism. As for the epistemology of metamodern (as if), and its ontology (between), it should therefore be regarded as a "Both-and" dynamics. They are both modern and postmodern at the same time, and not one of them.

Metamodernism obviously expresses itself through an a-topical metaxis. The Greek-Eng-

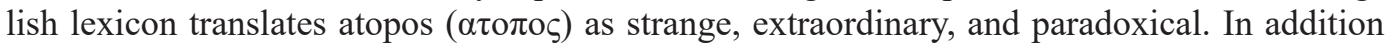
to this taxis ( $\tau \alpha \dot{\xi}(\varsigma)$ means ordering. Consequently, metamodern should be understood as space-time, which is simultaneously neither in order nor in disorder. It is important to note that Dutch scientists say the following about the appointment of metamodernism: "Metamodernism replaces the boundaries of the present with the limits of a hopeless future; and he replaces the boundaries of familiar places with the boundless. In fact, this is the "fate" of metamodern man: to pursue the infinitely retreating horizons " (Vermyulen, Akker, 2015).

\section{Hypermodernism}

Analyzing the current reality one cannot underestimate the high pace of life processes associated with the spread of technology, information and mass infection.

In relation to these aspects, the French philosopher and sociologist Gilles Lipovecki combined practical observations with scientific research to create an understandable picture of Western society. Forget about postmodernism the scientist says, now we are entering the era of hypermodernism. According to the scientist this era began in 1989.

The essence of the problem comes down to the appearance of two phenomena. Firstly, the growth of neoliberal policies has led to increased capitalism and extreme competition. Secondly, the explosion of technology and communications has contributed to cultural "instantness" and "speed" which increases people's desire for momentary enjoyment. The Internet and other similar technologies allow you to get things fast which is what people want.

The author shows great interest in consumer issues and consumers which puts him on a par with market researchers. The philosopher describes the time as "hyper": everything is "too much". Lipovecki sees hypermodernity as a culture of excess, oversaturation and too fast a pace.

The author observes that we no longer live in an atmosphere of an epilogue to modernism: we simply forgot about it. The point of view seems to be reasoned according to which today is a crazy move forward an overabundance of goods, information, raging equipment that carries as many dangers as good.

Modernity, globalized and without rules, lives on the principles of a market economy, fierce competition, maximum efficiency and a vibrant personality. Therefore, everything is too much: circulation of capital around the planet, hyperreal speed of financial transactions, delocalization and privatization, commercial centers and hypermarkets overflowing with goods, the Internet hyper galaxy and the vast flow of information, the movement of huge masses of people - mass tourism and "world consumption". Records, doping, serial killers, hyper-fat men, hyper-diets, manic care for hygiene and your health - the "medicalization" of life. Hyper-individualism rushes 
from one extreme to the other: it carefully calculates, wins or rushes into unbalanced anarchy. Both measure and lack of measure are at the same time. The moral-ideological model no longer exists: society in its unconscious search turns to the earlier layers of civilization and gladly integrates into itself everything that rejected 20th-century modernism. Nobody destroys the past anymore, it is inserted into the present and processed in the spirit of the modern logic of consumption, market and individualism. The hyperconsumer no longer contemplates the past in silence, but swallows it in a few seconds in search of constant diversity, entertainment, momentary emotion. The past becomes a way of mass animation: achieving comfort not only material, but also intellectual, existential. In a duet with hypermodernity the past becomes like an old building behind the preserved facade of which a new filling is hidden (Elistratova, 2007). One cannot disagree with the author of the indicated theory and note that hypermodern undoubtedly rapidly penetrates time and space, omnipresent penetrating into all spheres of human life.

\section{Performatism}

Raul Eshelman Slavic professor at the Ludwig Maximilian University in Munich, proposes to consider modern culture in the form of performatism. In his understanding the subject should be presented as integrity, unity, which will certainly impress the reader or viewer. The process of unity with the subject is possible only when the subject does not semantically differentiate the content of the work because upon closer examination the content can be scattered in the context surrounding it. In order to avoid such a dissolution of the essence, now the themes of the work should always be simple to understand, the content and form should become identical and the designation should coincide with the internal essence. Performatism is characterized by the promotion of self-therapy the idea that we can overcome the power of a rampant, repressive environment by only repeatedly affirming our own self. Performativity is also manifested in the plurality of chronotopes of the storyline of the work and the ability to manage them which are given to the main characters. According to Eshelman postmodernism provides neither time nor space for the development of causal relationships.

Chronotopes occur and diverge almost simultaneously. In contrast in the new era of performatism there is a tendency to create chronotopes that allow multiple choices between possibilities. Unexpectedness is now the prerogative of the subject not the sign: the essence is to maintain the integrity of the subject even under the most adverse conditions (Tormakhova, 2016).

\section{Conclusion}

In conclusion it should be noted that all the presented theories have in their basis a specific concept, definition, key aspects, characteristics that allow us to familiarize ourselves in more detail and determine the characteristic features and features that smoothly flow into something new or just a nascent cultural stage development. Each of the theories puts forward its own set of methodological claims. Theories are built on various foundations. The foregoing allows us to say that some authors consider the transformation in the external and internal world of mankind as the impact of computerization and digital technologies (A. Kirby) as a result others add mechanical automation to this, thereby provoking an increase in the degree of personal autonomy (R. Samuels). Still others view the epoch through the prism of oscillation and argue that with the help of eclecticism of modernism and postmodernity we can now observe a new emerging era - metamodernism (R. Akker, T. Vermeulen).

In the conventionally called era of "post-postmodernism" the theories of scientists are carried away by universalization, hypermedicalization and hyperconsumption, creolization and new 
forms of textuality, the reality of technological being. Numerous studies show that information and technology have a decisive influence on the emergence of a new historical and cultural era.

With all certainty it can be argued that each of us in some way feels on ourselves the specific characteristics of each of the above concepts and to give credit to one, specific factor, would not be rational and at least illogical. Thus, the synthesis of the presented key aspects of each of the concepts with the help of which an excellent complex theory can be formed and can be considered appropriate.

In conclusion we can say that this stage of historical, spiritual, moral, technical, economic, cultural and social formation on which mankind is faces now we should further comprehend, explore and realize. One cannot fail to notice that despite the apparent multidimensionality and vastness of research many more properties and mechanisms of the new cultural and historical period are not well understood and therefore require attention and additional consideration. In conclusion it should be noted that researchers and scientists have still not agreed on the definition of a single and clear concept that would reflect the essence of the present cultural-historical period.

\section{References}

Bespalaya, O. (2014). Posle postmoderna: al'termodern, transmodern, postpostmodern.... [After postmodern: altermodern, transmodern, post-postmodern...] Gumanitarny'e, soczial 'noe'konomicheskie i obshhestvenny'e nauki., 1-6. URL: https://cyberleninka.ru/article/n/poslepostmoderna-altermodern-transmodern-postpostmodern/viewer. (in Russian)

Elistratova, L. (2007). Fiziologicheskaya fantaziya. [Physiological fantasy] Vremya. URL:http:// www.e-reading.club/chapter.php/21985/31/lola-elistratova-fiziologicheskaya-fantaziya.html (in Russian)

Kirby, A. (2006). The Death of Postmodernism and Beyond. Philosophy Now. URL: https:// philosophynow.org/issues/58/The_Death_of_Postmodernism_And_Beyond (in English)

Komarniczkaya, L. (2009). Al'termodern poluchil global'ny'j status. [Alterodern gains global status] Live Jounal. URL: https://top10-kiev.livejournal.com/135452.html. (in Russian)

Kuzneczov A. Yu. (2019) Do genezi metamoderni'zmu. [Towards the genesis of metamodernism] Humanities Journal. 7-17. doi:10.32620/gch.2019.1.01 (in Ukrainian)

Lipoveczki, Zh. (2013). Vy'soka kul'tura vs. massovaya kul'tura. [High culture vs mass culture] URL: http://gefter.ru/archive/9836. (in Russian)

Mitroshenkov,O.(2016). Chto pridetna smenupostmodernizmu? [What will replacepostmodernism?]

URL: http://metamodernizm.ru/chto-pridet-na-smenu-postmodernizmu/ (in Russian)

Nechaev, I. (2010). Avtomodernizm kak napravlenie zapadnoj kul'turofilosofii. [Automodernism as a direction of Western cultural philosophy] Nauchny'e trudy' Moskovskogo gumanitarnogo universiteta, 119. URL: www.culturalnet.ru/main/getfile/2571 (in Russian)

Osipova, O N. (2014). Postmodernistkij sindrom: kul'turny'j shok ili "dolgoe proshhanie"? [Postmodern Syndrome: Culture Shock or Long Goodbye?] Vestnik Vyatskogo gosudarstvennogo universiteta, 11-15. (in Russian)

Pavlov, A. (2019). Vidy' postpostmodernizma. [Types of post-postmodernism] URL: https:// postnauka.ru/video/96268 (in Russian)

Postpostmodernism. (2020). In Vikipedia. [Postpostmodernism] URL: https://ru.wikipedia.org/ wiki/Постпостмодернизм (in Russian)

Tormakhova, A. (2016). Iskusstvo $v$ teoriyakh post-postmodernizma. [Art in post-postmodern theories] Studia Culturae, 1(27), 18-26. URL: http://iculture.spb.ru/index.php/stucult/article/ viewFile/699/694. (in Russian) 
Vermyulen, T, \& Akker, $R$ v. (2015). Zametki o metamodernizme. [Notes on Metamodernism] URL: http://metamodernizm.ru/notes-on-metamodernism (in Russian)

Vermeulen, T., \& Akker, R. V. (2010). Notes of metamodernism. Journal of Aesthetics \& Culture., 1-14. URL: http://www.emerymartin.net/FE503/Week10/Notes\%20on\%20Metamodernism.pdf (in English) 